\title{
Egg and faecal pellet production of Calanus finmarchicus females from controlled mesocosms and in situ populations: influence of age and feeding history
}

\author{
Catherine Rey ${ }^{1, *}$, François Carlotti ${ }^{1}$, Kurt Tande ${ }^{2}$, Bent Hansen Hygum ${ }^{3}$ \\ ${ }^{1}$ Université P. et M. Curie (Paris VI), Station Zoologique, URA 2077, CNRS/INSU, BP 28, \\ 06230 Villefranche-sur-Mer, France \\ ${ }^{2}$ University of Tromso, The Norwegian College of Fishery science, 9000 Tromso, Norway \\ ${ }^{3}$ Roskilde University, Dept of Life Sciences \& Chemistry, 4000 Roskilde, Denmark
}

\begin{abstract}
Egg and faecal pellet production of Calanus finmarchicus females were investigated individually under superabundant food conditions at 5 and $10^{\circ} \mathrm{C}$. The females came from (1) in situ populations in the Raunefjord (southern Norway) in March and May 1997 and (2) cohorts reared in 2 mesocosms, one with high $(\mathrm{H})$ and one with low (L) food concentrations. The egg production rates of newly moulted females coming from mesocosms increase from zero to maximal rates over 10 to $15 \mathrm{~d}$ at 10 and $5^{\circ} \mathrm{C}$, respectively. The delay in reaching maximal fecundity rates depends on time required for gonad maturation, which is related to the use of storage lipid and also to food supply for ending the maturation. The faecal pellet production rates also increase with time, suggesting that fecundity is governed by ingestion. Finally, we suggest a conceptual model of different events between moulting and optimal spawning activity in newly moulted females in superabundant food conditions. The fecundity, egestion and lipid metabolism of wild females (caught in March and May) were studied in the same way. The results are compared to observations of young females from mesocosms and the influence of seasonal origin of females on the studied processes is assessed. Data from experiments run with females from Mesocosms $\mathrm{L}$ and $\mathrm{H}$ permit us to discuss the effect of feeding history on fecundity and egestion. Although females from Mesocosm L show shorter prosome lengths than those from Mesocosm $\mathrm{H}$, fecundity is not significantly different. However, females from Mesocosm L have a much higher production of faecal pellets than females from Mesocosm $\mathrm{H}$, suggesting that the previous food limitation during copepodite development in Mesocosm $\mathrm{L}$ induces higher maximal ingestion rates of these females than the previous well-fed females (Mesocosm H). A few assumptions to explain these different patterns are proposed.
\end{abstract}

KEY WORDS: Calanus finmarchicus $\cdot$ Mesocosm $\cdot$ Egg production - Faecal pellet production - Age Feeding history

\section{INTRODUCTION}

Estimates of secondary production are essential to assess fluxes of organic material in the ocean. For copepods, different methods are used depending on developmental stages. One popular method for the non-growing females is to measure the egg production (Poulet et al. 1995, Hirche 1996b). Numerous studies

\footnotetext{
•E-mail: rey@ccrv.obs-vlfr.fr
}

have focused on the equivalence of copepodite growth rate and female egg production rate when individuals are maintained in similar environmental conditions (Sekiguchi et al. 1980, Smith \& Lane 1985, Kiørboe \& Sabatini 1995, McLaren \& Leonard 1995).

To compare fecundity of females in space and time, it is important to understand sources of variability in the spawning rate. Natural environmental conditions such as temperature and food supply are responsible for a large part of this variability (Peterson et al. 1991, Hay 1995, Pond et al. 1996, Cabal et al. 1997). Laboratory 
studies have focused on the variation of egg production under different but constant environmental conditions (Checkley 1980, Runge 1984, Peterson 1988, Hirche 1990, Hirche et al. 1997). More recent studies have investigated the effects of fluctuations of food supply which might better reflect in situ patchy food conditions (on large copepod species: Carlotti \& Hirche 1997. Hirche et al. 1997; on small copepod species: Dagg 1977, Nival et al. 1990).

These studies show that fecundity varies considerably among females incubated under similar conditions of temperature or food supply (see fecundity values reviewed by Kiorboe \& Sabatini 1995 and Charlotti \& Hirche 1997). Part of this variability is known to be due to different experimental procedures (Laabir et al. 1995, Miralto et al. 1996, Cabal et al. 1997, Saiz et al. 1997). But, individual variability, including factors such as genetic background, age and feeding history, has also been reported to influence the measurement of bioenergetic processes (Båmstedt 1988, Paffenhöfer 1994). For example, high variability in fecundity and egestion rate was observed over the female life span of Centropages typicus (Carlotti et al. 1997). This age effect can introduce considerable bias when 'mean values' are used to determine bioenergetic processes.

Feeding history also influences physiological processes of copepods in the natural environment (Båmstedt \& Tande 1988, Huntley 1988). To evaluate the effect of feeding history, it is necessary to perform long-term studies in which the nutritional history of the animals is known prior to experimentation. Hasset \& Landry (1983, 1990) and Harris et al. (1986) have shown the influence of different quantitative and qualitative food sources on copepod feeding over an extended period of acclimation. However, no studies have been conducted to assess the impact of nutritional history on fecundity.

The aim of the present study is to evaluate the impact of age and feeding history of Calanus finmarchicus females, a key copepod species of the northern marine ecosystem, on fecundity and egestion. The latter is assumed to be an index of ingestion (Nejstgaard 1997). Newly moulted females from cohorts previously reared in mesocosms at different food levels were used in laboratory experiments on egg and faecal pellet production. Lipids were also estimated on females before and after experimentation as well as the gonad maturation stage, since the use of lipid is often related to the gonad maturation in young females (Sargent \& Falk-Petersen 1988, Plourde \& Runge 1993). Similar experiments were conducted with wild females from the natural environment in order to compare their functional responses with those of young females from mesocosms.

\section{METHODS}

Overview of the mesocosm study. Zooplankton samples were collected from Raunefjord (western Norway $60^{\circ} 17^{\prime} \mathrm{N}, 05^{\circ} 10^{\prime} \mathrm{E}$ ) on March 6, 1997, with a $500 \mu \mathrm{m}$ mesh plankton trawl. In the laboratory, samples were transferred to large containers placed at $5^{\circ} \mathrm{C}$ and fed with algal cultures. Every $24 \mathrm{~h}$, eggs produced by Calanus finmarchicus females were collected and transferred to $10 \mathrm{l}$ beakers. Two days later, hatched nauplii were inoculated in mesocosms for further studies on growth and development of the cohorts. The mesocosms were large enclosures $\left(18.5 \mathrm{~m}^{3}\right)$ filled with $50 \mu \mathrm{m}$ screened sea water which was enriched with different concentrations of nutrients (for details on the set-up of mesocosms, see Egge \& Heimdal 1994). Mesocosm L contained a cohort reared at a low food concentration, and Mesocosm $\mathrm{H}$ a cohort reared at a significantly higher food concentration (Table 1). Such differences between food levels in each mesocosm were sufficient to support different copepodite growth rates. Nauplii inoculated on March 10 in Mesocosm L were 2 d older than those inoculated on March 12 in Mesocosm $H$. The mesocosm study was performed until May 12. Every second or third day, samples of $C$. finmarchicus were collected in each mesocosm with a $25 \mathrm{~cm}$ diameter, $200 \mu \mathrm{m}$ mesh plankton net (226 1) and

Table 1. Minimum (min), mean, maximum (max) and standard deviation (SD) of total chlorophyll (chl a), chl a $<10 \mu m$, particulate organic carbon (POC) and nitrogen (PON) pools (retained on muffled Whatman GF/C filters) in mesocosms $\mathrm{L}$ and $\mathrm{H}$, recorded during the development of the last 2 copepodite stages $C 4$ and $C 5$, i.e values from the last month. Units are in $\mu g \mathrm{l}^{-1}$. Means of both mesocosms are significantly different (Student $t$-test, $p<0.05$ ) except for $\mathrm{chl} a<10 \mu \mathrm{m}(\mathrm{p}=0.145)$

\begin{tabular}{|lcccccccc|}
\hline & \multicolumn{4}{c}{ Mesocosm L } & \multicolumn{3}{c|}{} & \multicolumn{2}{c}{ Mesocosm H } \\
& Min & Mean & Max & SD & Min & Mean & Max & SD \\
\hline Total chl a & 0.383 & 0.917 & 1.760 & 0.374 & 0.655 & 1.91 & 4.670 & 1.23 \\
Chl $a<10 \mu \mathrm{m}$ & 0.164 & 0.450 & 0.769 & 0.211 & 0.436 & 0.570 & 0.719 & 0.083 \\
POC & 316 & 438 & 686 & 113 & 438 & 790 & 1773 & 423 \\
PON & 33.4 & 51.5 & 78.2 & 14.7 & 162 & 87.2 & 55.2 \\
\end{tabular}


preserved in $10 \%$ borax-buffered formaldehyde solution for later cohort analysis (Hygum et al. in press $a, b$ ).

Egg and faecal pellet production experiments. Egg production experiments were conducted with individual females held in $280 \mathrm{ml}$ of an algal solution in Plexiglas cylinders with $400 \mu \mathrm{m}$ mesh false bottoms suspended in $400 \mathrm{ml}$ beakers. Five batches (Expts $\mathrm{W}-5$, MH-5, W-10, MH-10 and ML-10) of 20 to 31 females were used in these experiments (Table 2). These females originated from samples from different sources (mesocosms $\mathrm{L}$ or $\mathrm{H}$ and in situ conditions in Raunefjord in March or May). The samples were first split in 2, one preserved for later analysis and the other one used for egg production experiments as outlined in Table 2.

Expts $\mathrm{W}-5$ and $\mathrm{MH}-5$ were run at constant $5^{\circ} \mathrm{C}$, with females obtained from Raunefjord (in situ) and from high food concentrations in Mesocosm $\mathrm{H}$, respectively. Expts $\mathrm{W}-10, \mathrm{MH}-10$, and ML-10 were run at constant $10^{\circ} \mathrm{C}$ with females from Raunefjord (in situ), and high (Mesocosm H) and low (Mesocosm L) initial food concentrations, respectively.

Fertilised females (i.e. with dark spermathecal sac) carrying a spermatophore on the first abdominal segment at the start of the experiments were identified. Females with a spermatophore were assumed to be the youngest. Since spermatophores are easily lost in nets during in situ sampling, only 1 case was found in Expt W-5 and none in Expt W-10.

On a daily basis, each cylinder containing the females was quickly placed in a new beaker with fresh food. Eggs and faecal pellets produced during the previous $24 \mathrm{~h}$ were counted under a dissecting microscope. During the first $3 \mathrm{~d}$ of Expt W-5 faecal pellets were not counted. In all experiments females were fed with cultures of Rhodomonas baltica ( 7 to $8 \mu \mathrm{m}$ ) at a superabundant concentration of 40000 cells ml-1 and maintained in the dark. The high food concentration was required to obtain maximal egg production rates because the filtering capacity of the females on this algae is known to be low (Carlotti \& Hirche 1997). At the end of each experiment females were preserved in formalin.
Individual analysis of preserved samples. Individual biometric characteristics (prosome length, prosome width and oil sac volume) were measured on females from the preserved fractionated samples collected before and after all experiments. Prosome length and width were measured with a micrometer (at $30 x_{i}$ to the nearest $40 \mu \mathrm{m}$ ). The relative oil sac volume (i.e. the ratio of oil sac volume to prosome volume) was measured under a microscope following Plourde \& Runge (1993). Because of the irregular width of the oil sac when it is fully extended along the length of the prosome, the volume was estimated from 2 ellipses when the oil sac crossed the limit of the first cephalothoracic segment. Maximal length of the first ellipse was measured from the front of the oil sac in the head to the end of the first cephalothorax segment. Maximal length of the second ellipse was measured from the end of the first cephalothoracic segment to the end of the oil sac.

The stage of gonad maturity of females isolated from the samples collected prior to experimentation was determined based on criteria described in Runge (1987). Reproductive index value was calculated as the ratio of actively spawning females (in gonadal development stages 4 to 7 ) to the total number of females (Runge 1987, Plourde \& Runge 1993).

The diameter of 50 eggs produced per 5 females in each experiment was measured under a microscope. The volume of 100 faecal pellets released per 10 females in Expts MH-10 and ML-10 was estimated with METAMORPH 2.75 software (Universal Imaging Corporation, West Chester, PA, USA) from video stored images. Faecal pellets were measured as cylinders. The length was arbitrarily chosen as the maximal length measured in several successive segments, as the shape of the faecal pellets was most of the time curved, and the diameter was arbitrarily chosen as the minimal width of the faecal pellets.

Statistical analysis. Statistical analyses were conducted using SYSTAT 7.0. The averages of egg and faecal pellet production for each experiment were compared with the non-parametric Kruskal-Wallis test followed by a multiple comparison test for unequal sample size (Scherrer 1984). One-tailed Student's $t$-tests of sig-

Table 2. Characteristics of the 5 egg production experiments. The number of fertilised females with and without their spermatophore at the start of experiments are indicated by nfs and nf respectively and the number of experimental days by nday

\begin{tabular}{|c|c|c|c|c|c|c|c|c|}
\hline \multirow[b]{2}{*}{ Expt W-5 } & \multirow{2}{*}{$\frac{\text { Temperature }\left({ }^{\circ} \mathrm{C}\right)}{5}$} & \multirow{2}{*}{$\begin{array}{l}\text { Initial date } \\
8 \text { March } 1997\end{array}$} & \multicolumn{3}{|c|}{ Origin of females } & \multirow{2}{*}{$\frac{\text { nfs }}{1}$} & \multirow{2}{*}{$\begin{array}{l}\mathrm{nf} \\
30\end{array}$} & \multirow{2}{*}{$\frac{\text { nday }}{44}$} \\
\hline & & & In situ & - & $5.5^{\circ} \mathrm{C}$ & & & \\
\hline Expt MH-5 & 5 & 9 Мay 1997 & Mesocosm H & High food & $7.9^{\circ} \mathrm{C}$ & 10 & 10 & 14 \\
\hline Expt W-10 & 10 & 14 May 1997 & In situ & - & $8.1^{\circ} \mathrm{C}$ & 0 & 25 & 9 \\
\hline Expt $M H-10$ & 10 & 7 May 1997 & Mesocosm H & High food & $7.4^{\circ} \mathrm{C}$ & 11 & 14 & 16 \\
\hline Expt ML-10 & 10 & 7 May 1997 & Mesocosm L & Low food & $7.4^{\circ} \mathrm{C}$ & 10 & 15 & 16 \\
\hline
\end{tabular}


nificance of slope were done to determine whether the mean faecal pellet production versus day significantly decreased after maximum values were reached.

The averages of prosome length (data were arcsin transformed to satisfy ANOVA hypothesis) and egg diameter for each experiment were compared with 1 -way variance analysis and Tukey's test for multiple comparison. Faecal pellet volumes were tested for normal distribution. The oil sac volume of copepodite stage C5 and females before and after the experiments were separately compared with the non-parametric Kruskal-Wallis test followed by a multiple comparison test.

In each experiment, multilinear regression models were used (the assumptions were previously checked and females which did not spawn were not considered) to explain the variability of individual mean rates of egg production $(Y)$ as a function of 2 independent variables: the prosome length $\left(X_{1}\right)$ and the individual mean rates of faecal pellet production $\left(X_{2}\right)$. The model used was:

$$
Y=b_{1} \times X_{1}+b_{2} \times X_{2}+\text { constant }
$$

where the $b_{1}$ and $b_{2}$ terms are parameters of the 2 independent variables, respectively. Student's $t$-tests were conducted to test significance of both parameters.

\section{RESULTS}

\section{Population characteristics of females from mesocosms}

Most of the females in both mesocosms were already fertilised and had lost their spermatophores. Females not yet fertilised (i.e. with transparent spermathecal $\mathrm{sac}$ ) were only found once. The females from mesocosms used in our spawning experiments (Expts $\mathrm{MH}-5$, MH-10 and ML-10, see Table 2) had just moulted and were at most $1 \mathrm{wk}$ old (Hygum et al. in press b).

\section{Individual time series of daily egg and faecal pellet production}

Time series of all females from 2 experiments (Expts W-5 and $\mathrm{MH}-10$ ) were selected to compare individual profiles of egg and faecal pellet production obtained at 5 and $10^{\circ} \mathrm{C}$ (Figs. $1 \& 2$ ). These experiments were chosen because Expt W-5 was an example of a long time series (44 d) and Expt MH-10 commenced with young females.

Different spawning patterns at $5^{\circ} \mathrm{C}$ were observed (solid lines in Fig. 1): (1) regular egg production around 50 eggs $\mathrm{d}^{-1}$ during the whole experiment (f2); (2) regular egg production with several peaks around 100 eggs $d^{-1}$ (e.g. $\{3, f 6, f 10, f 16)$; (3) regular egg production with several zero values ( $f 8, f 21, f 25, f 27)$; (4) discontinuous egg production with strong fluctuations ( $f 1, f 17, f 23$, f24). Regularity of the spawning rhythms for some of these patterns is quite remarkable (f8, f21, f24, f29). In several profiles of faecal pellet production (dashed lines), the highest rates were over the period from Day 5 to 15 (f2, f4, f5, f6, etc.). After this time period, faecal pellet production almost followed the same pattern as for the egg production. Individual rhythms of egg and faecal pellet production were often very similar (f10, f12, f20, f29).

At $10^{\circ} \mathrm{C}$ (Fig. 2) peaks of about 100 eggs $\mathrm{d}^{-1}$ were much more frequent than at $5^{\circ} \mathrm{C}$ (Fig. 1), suggesting that 2 clutches were released. The start of spawning is not immediate and it appears even later (from 2 to $7 \mathrm{~d}$ ) for females carrying a spermatophore at the beginning of the experiment. For females with a spermatophore, faecal pellet production was also lower during the first experimental days.

In all time series (Figs. $1 \& 2$ and other experiments), faecal pellet production fluctuated less (no peaks, no zero values) than egg production. Also, 'abnormal' profiles occurred in all experiments: females which die during the experiment (e.g. f13 in Fig. 1); females which do not produce any eggs or very few (average less than $20 \%$ of the total average of the experiment e.g f5 in Fig. 2); females which stop spawning for several successive days (for more than a third of the experimental time period, e.g. f18 in Fig. 1). Considering all experiments, 20 'abnormal' females out of the 126 used in total were observed.

\section{Egg and faecal pellet production versus time}

The mean egg production versus time (Fig. 3A) was calculated separately for females with (Fs) and without (F) a spermatophore at the start of the experiments. The mean egg production of the F females (solid line in Fig. 3A) showed 2 successive phases in all experiments except in Expt W-10. The first phase was an increase in the egg production during a period which varied from $6 \mathrm{~d}$ (Expts MH-10 and ML-10) to more than $12 \mathrm{~d}$ (Expt $\mathrm{MH}-5$ ). The second phase was characterised by more stable spawning rates which remained high over the rest of the experimental period. The highest rates at $5^{\circ} \mathrm{C}$ were around 40 to 50 eggs $\mathrm{d}^{-1}$ (Expts $\mathrm{W}-5$ and $\mathrm{MH}-5)$ whereas those at $10^{\circ} \mathrm{C}$ were greater than 60 eggs $d^{-1}$ (Expts W-10, MH-10 and ML-10).

The mean egg production of the Fs females dashed line in Fig. 3A) showed a similar pattern to that found for $F$ females. However, there were 2 main differences: first, the spawning activity started not immediately, but from 1 to 3 d later; second, the period of increased spawning activity was longer and varied from $\sim 10 \mathrm{~d}$ at 
$10^{\circ} \mathrm{C}$ (Expts $\mathrm{MH}-10$ and ML-10) to $-15 \mathrm{~d}$ (for the only Fs in Expt W-5) and to more than $12 \mathrm{~d}$ in Expt MH-5 at $5^{\circ} \mathrm{C}$. The standard errors for egg production data were smaller at $5^{\circ} \mathrm{C}$ (since usually 1 clutch and sometimes no eggs were produced per day, see Fig. 1) than at $10^{\circ} \mathrm{C}$ (where females released 1 or 2 clutches $\mathrm{d}^{-1}$ ) (Fig. 3B). Therefore, the highest standard error obtained at $10^{\circ} \mathrm{C}$ was due more to variability within the individual time series than between them.

The mean faecal pellet production versus time for each experiment (Fig. 4A) also demonstrated an initial increasing phase which was longer for the Fs females than for the $F$ females. These similarities in production rates of eggs and faecal pellets suggested a close relationship between spawning and ingestion processes. However, there were 2 differences: (1) the optimum egestion rates at $10^{\circ} \mathrm{C}$ were significantly higher in Expt ML-10 ( 80 faecal pellets $\mathrm{d}^{-1}$ ) than in Expts $\mathrm{W}-10$ and $\mathrm{MH}-10(\sim 60)$ and (2) the egestion rates decreased significantly after reaching maximum values in all experiments (Student's t-test of significance of slope, $\mathrm{p}<0.05$ ) except Expt $\mathrm{MH}-5$, where the egestion rate still increased.

\section{Analysis of mean rates of egg (MEP) and faecal pellet (MFP) production}

Two analyses of the MEP were performed (Table 3). In the first analysis (Analysis 1) the whole data set was used to calculate the MEP. The lowest mean egg production was observed in experiments run at $5^{\circ} \mathrm{C}$ (Expts $\mathrm{W}-5$ and $\mathrm{MH}-5)$, but the mean values of those experiments differed significantly. Mean egg production rates of females from both mesocosms held at $10^{\circ} \mathrm{C}$ (Expts $\mathrm{MH}-10$ and $\mathrm{ML}-10$ ) were similar and in the same range as those from in situ females held at 5 and $10^{\circ} \mathrm{C}$ (Expts $\mathrm{W}-5$ and $\mathrm{W}-10$ ). Coefficients of variation (CV) were high in all the experiments and the lowest CV was found in Expt $W-5$, mainly due to it having the longest duration ( $44 \mathrm{~d}$ ).
The second analysis of MEP was made using a selected data set (Analysis 2, Table 3). Zero or values inferior to 10 eggs obtained during the first experimental days were not used in this analysis. Compared to mean rates in Analysis 1, MEP from Expts W-5 and W-10 increased by only $~ 5 \%$. For MEP of females from mesocosms, the increase was higher at $5^{\circ} \mathrm{C} 133 \%$ for Expt $\mathrm{MH}-5)$ than at $10^{\circ} \mathrm{C}(-20 \%$ for Expts $\mathrm{MH}-10$ and ML-10). The difference between mean rates of Expts W-5 and MH-5 was reduced compared to those in Analysis 1, and the difference between mean rates at 5 and $10^{\circ} \mathrm{C}$ was increased. In Analysis 2, CV strongly decreased compared to those in Analysis 1. Significant differences between MEP from all experiments were found ( $\mathrm{Hc}=220, \mathrm{p}<0.001)$ and multiple comparisons allowed the 3 groups to be distinguished.

To estimate the MFP, the same selected data were used as those in Analysis 2 of the MEP (Analysis 2, Table 3). In all experiments, the CV were lower than those found for the egg production. Significant differences were found between all MFP ( $\mathrm{Hc}=278, \mathrm{p}<$ $0.001)$. Multiple comparisons indicated 3 different groups. The MFP at $10^{\circ} \mathrm{C}$ was significantly higher for females from Mesocosm L (Expt ML-10) than those from Mesocosm H (Expt MH-10). The hypothesis that the volume of faecal pellets released by females from both mesocosms was not significantly different, was tested and accepted $(\mathrm{Zc}=0.06, \mathrm{p}=0.48$, mean value $=3.5 \times 10^{6} \mu^{3}$ ). Thus, the significant difference between the egestion rates of Expts $\mathrm{MH}-10$ and ML-10 cannot be due to differences in the volume of faecal pellets.

\section{Prosome length, prosome width, egg diameter}

The smallest females were the in situ females collected in March (Expt W-5) and the largest ones originated from Mesocosm $\mathrm{H}$ (Expts MH-5 and $\mathrm{MH}-10$

Table 3. Calanus finmarchicus. Mean rates of egg and faecal pellet (FP) production female ${ }^{-1} \mathrm{~d}^{-1}$ for the 5 experiments calculated in Analysis 1 (all data) and in Analysis 2 (without data - for eggs or faecal pellets - where the number of eggs obtained for the first experimental days was $<10$ ). Mean rates that share the same superscripted letter are not significantly different at $5 \%$ (Kruskal-Wallis test followed by multiple comparison). n: total number of data, SD: standard deviation, CV: coefficient of variation

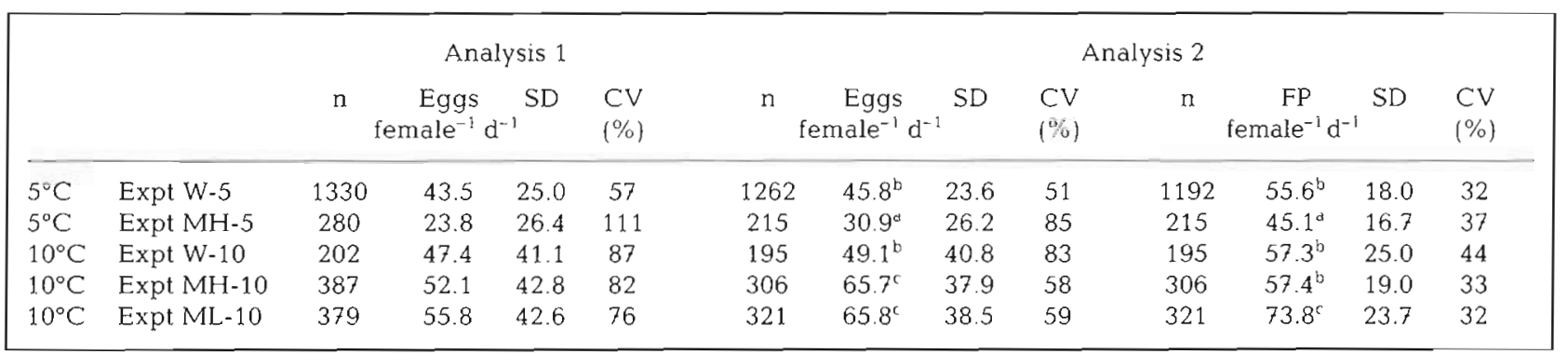



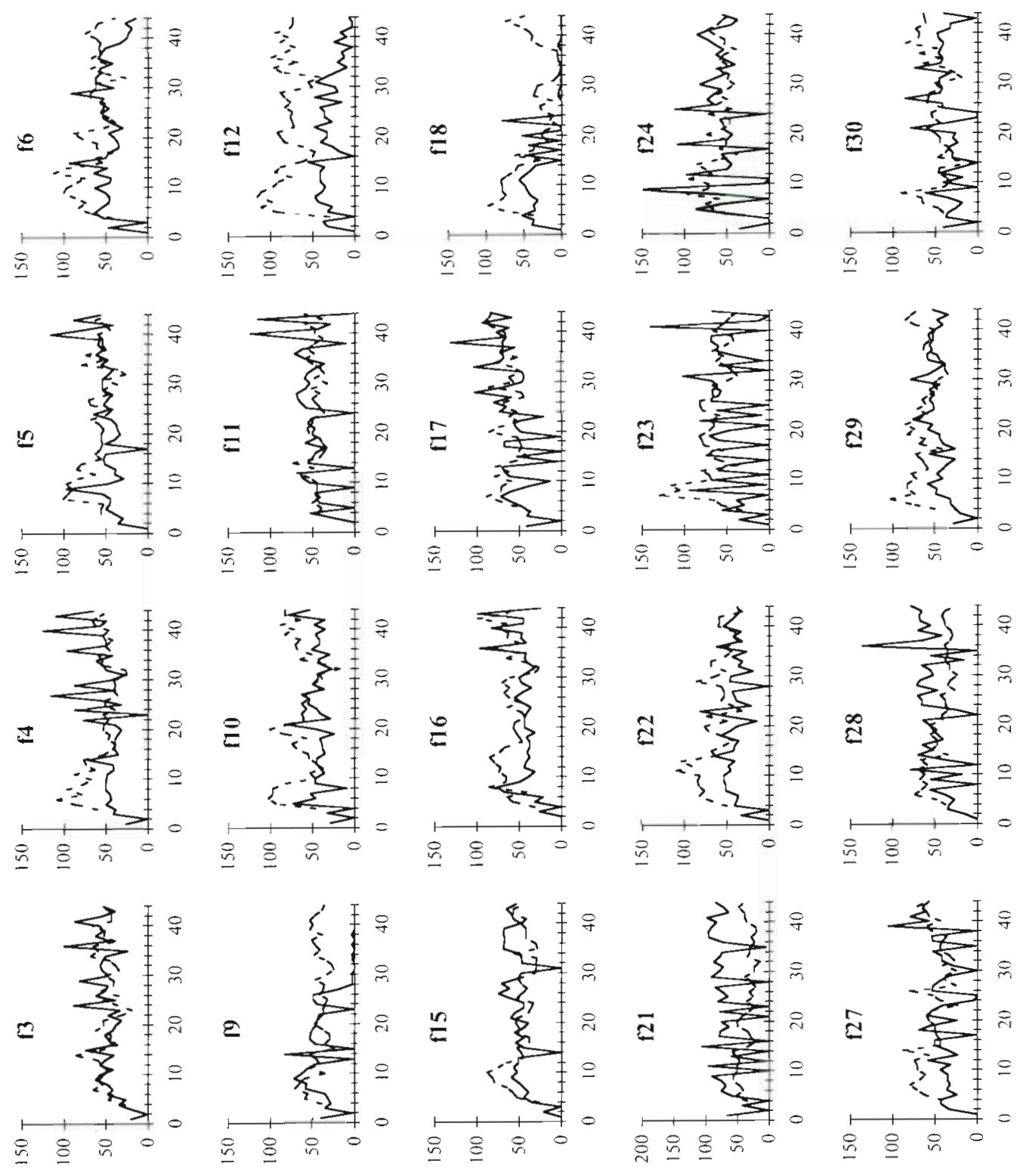

$\stackrel{乛}{0}$
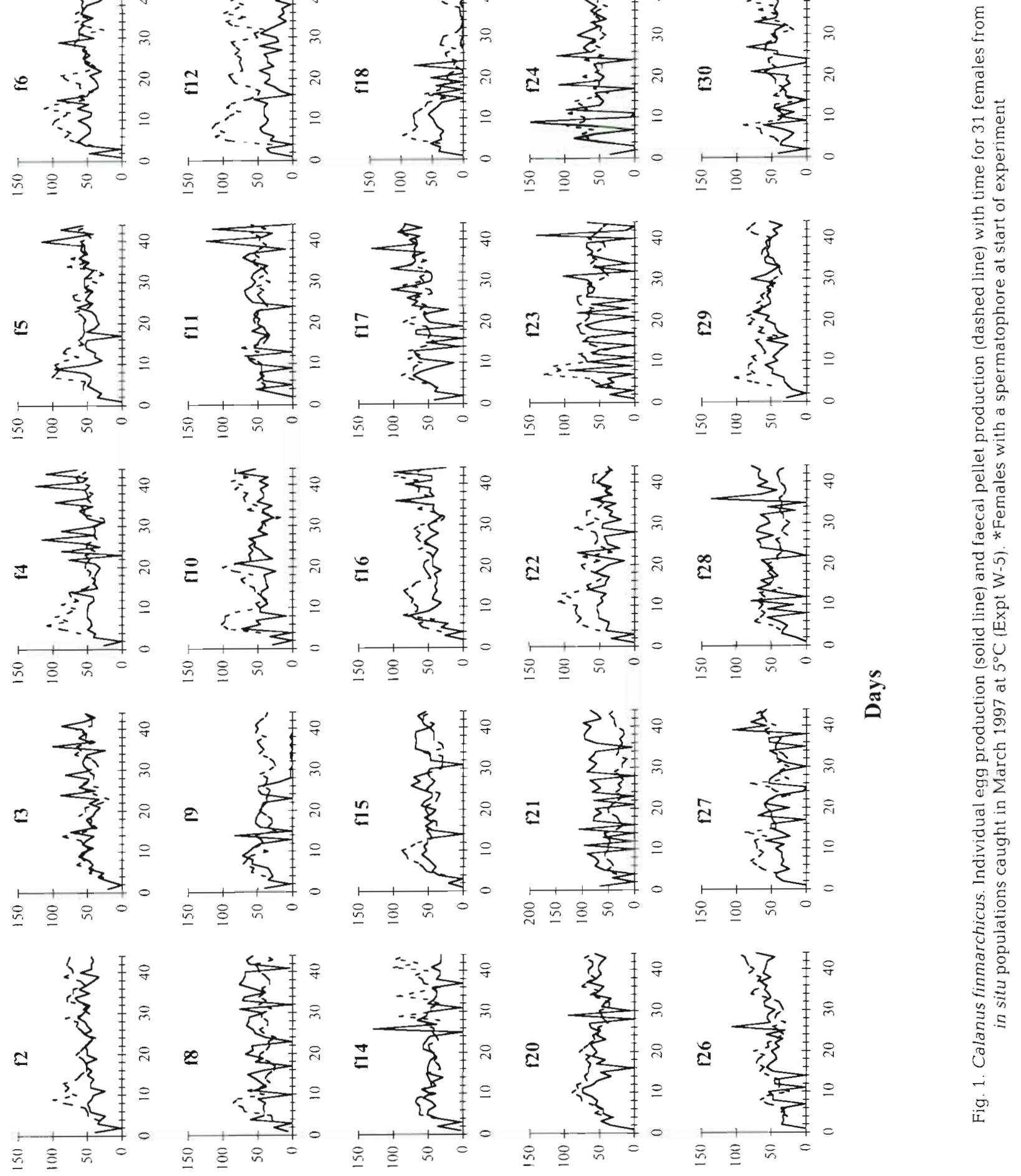

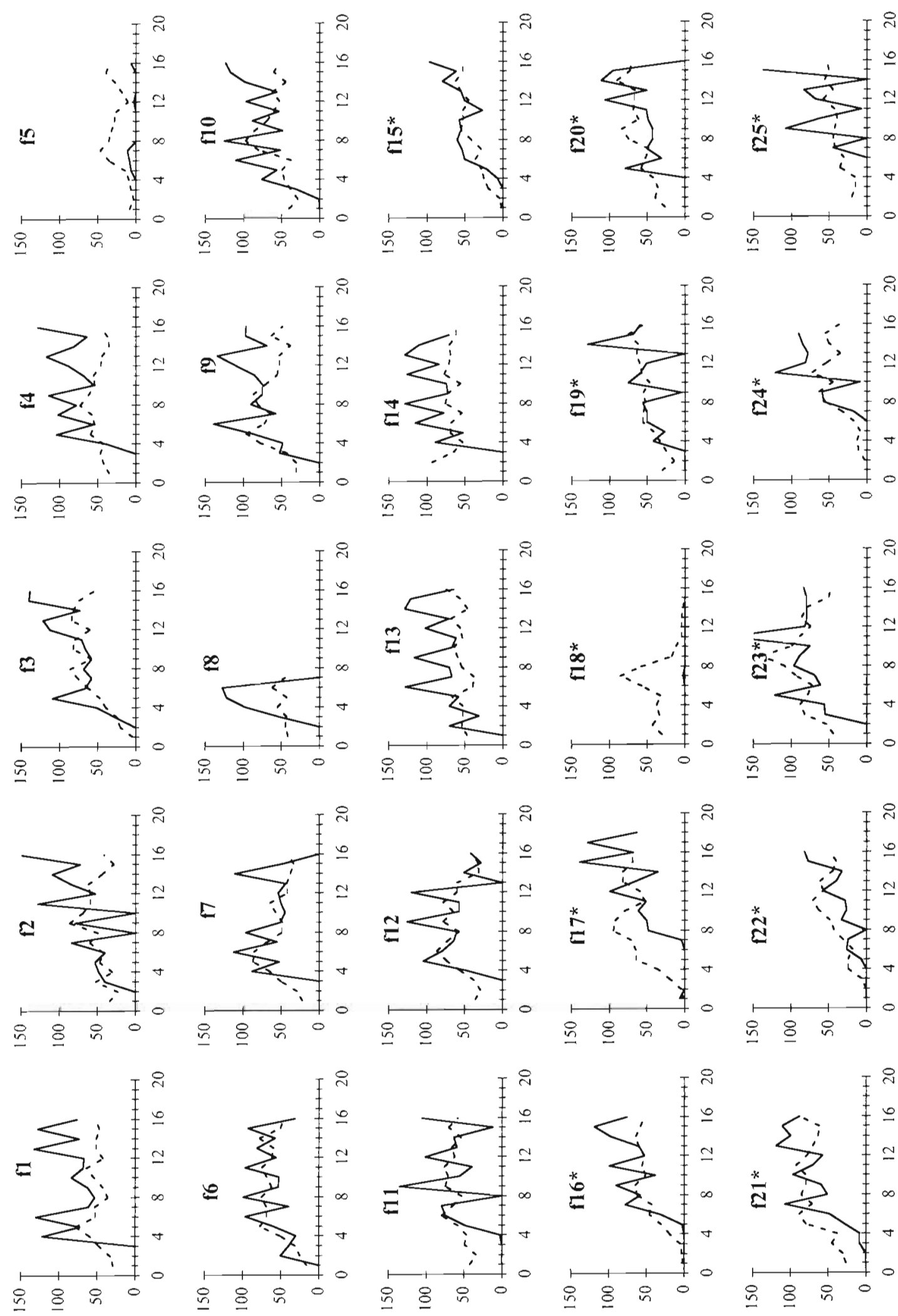
A
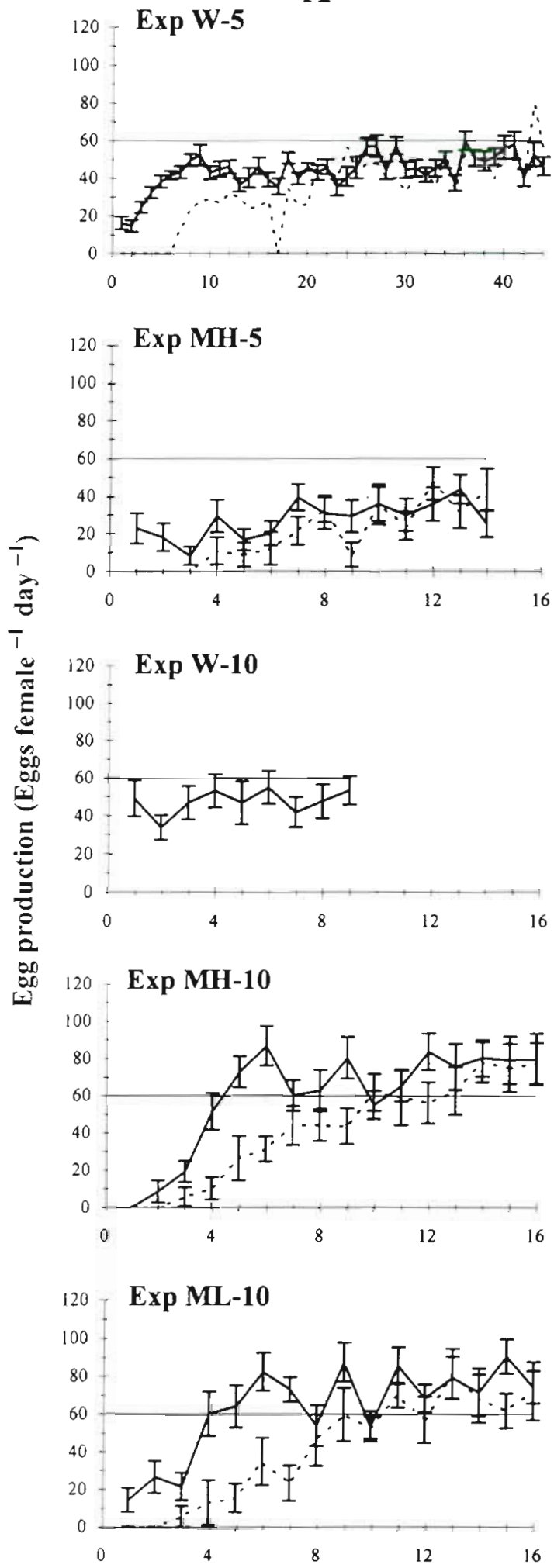

B

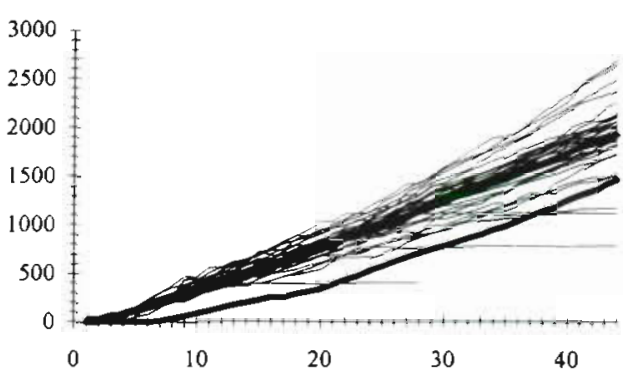

$5^{\circ} \mathrm{C}$

$5^{\circ} \mathrm{C}$

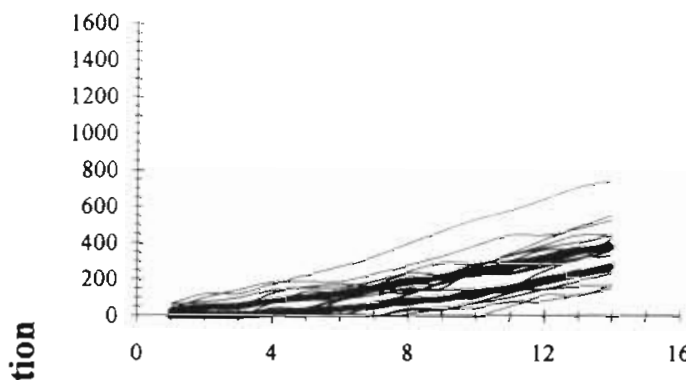

$10^{\circ} \mathrm{C}$
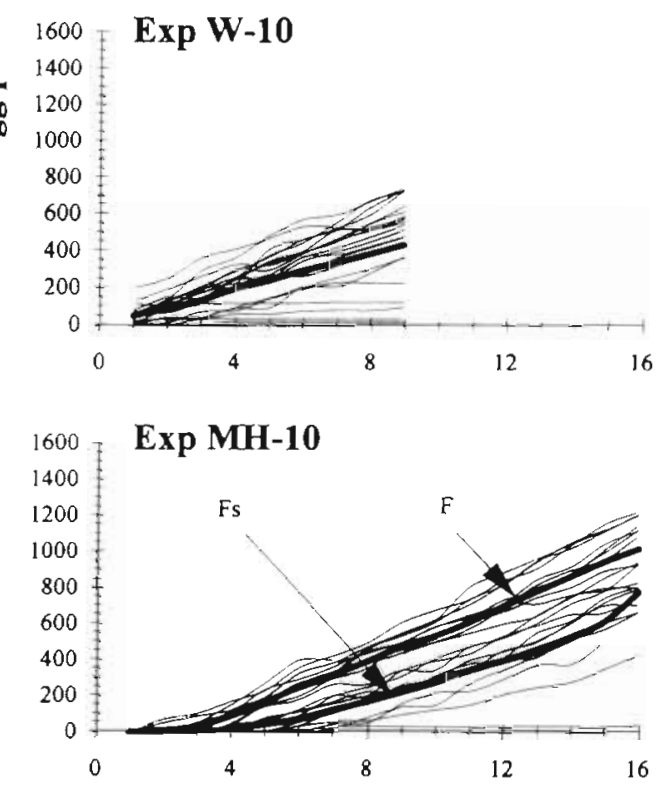

$10^{\circ} \mathrm{C}$

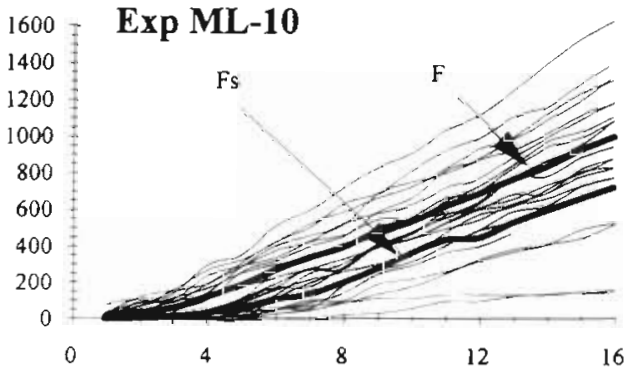

Fig. 3. Calanus finmarchicus. (A) Mean egg production with time for females incubated at 5 (Expts $\mathrm{W}-5$ and $\mathrm{MH}-5$ ) and $10^{\circ} \mathrm{C}$ (Expts W-10, MH-10 and ML-10). Dashed line and solid line represent females with and without a spermatophore at start of experiments, respectively. Vertical bars indicate standard error. Notice that the temporal scale in Expt W-5 is different than in other experiments. (B) Individual cumulative egg production. Thick lines represent mean cumulative rates of females with (Fs) or without (F) a spermatophore 
A
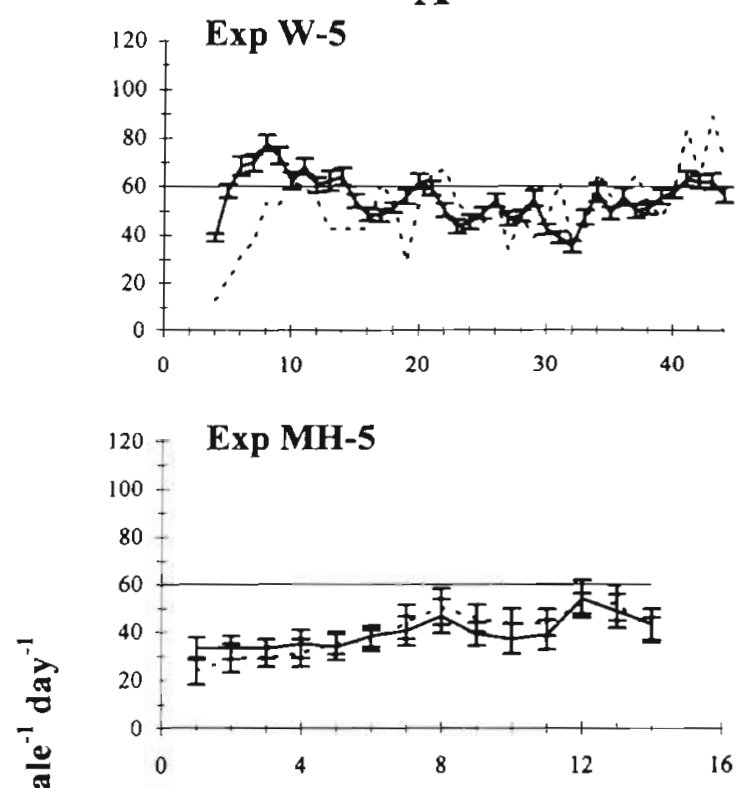

$120-\operatorname{Exp} \mathbf{W}-10$

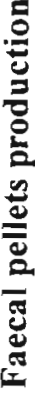
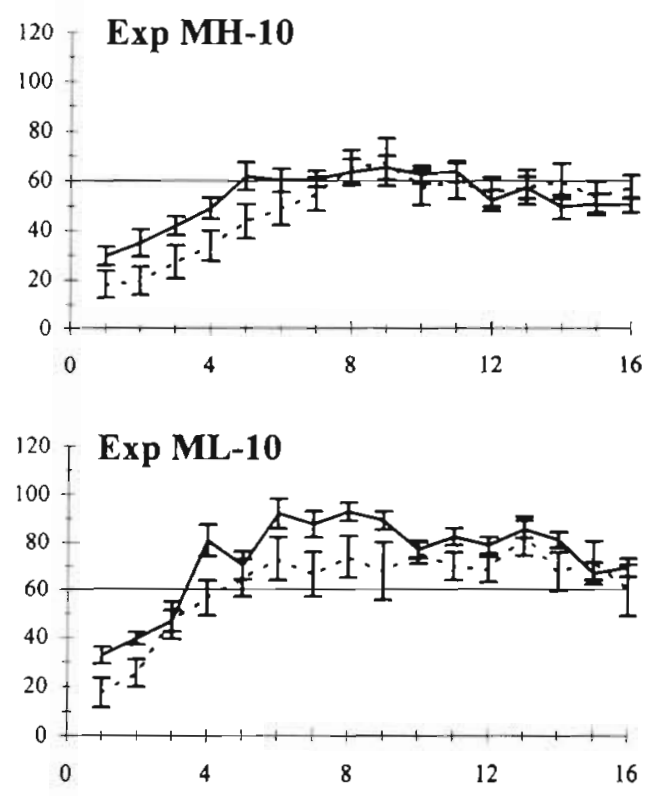

B

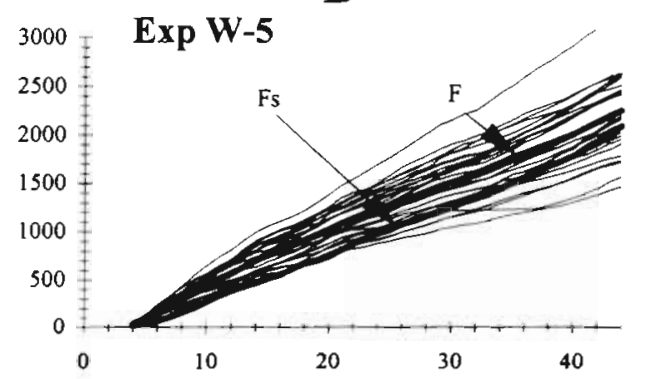

Exp MH-5

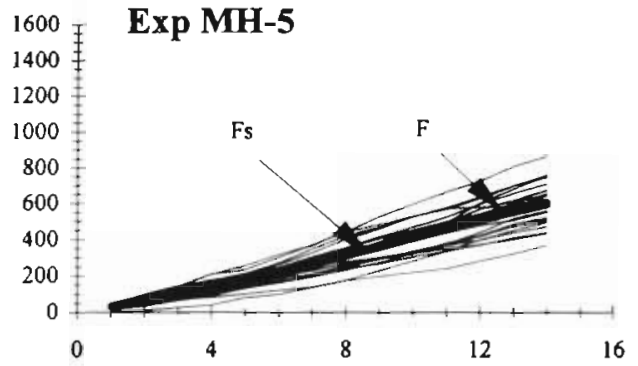

$5^{\circ} \mathrm{C}$

$10^{\circ} \mathrm{C}$
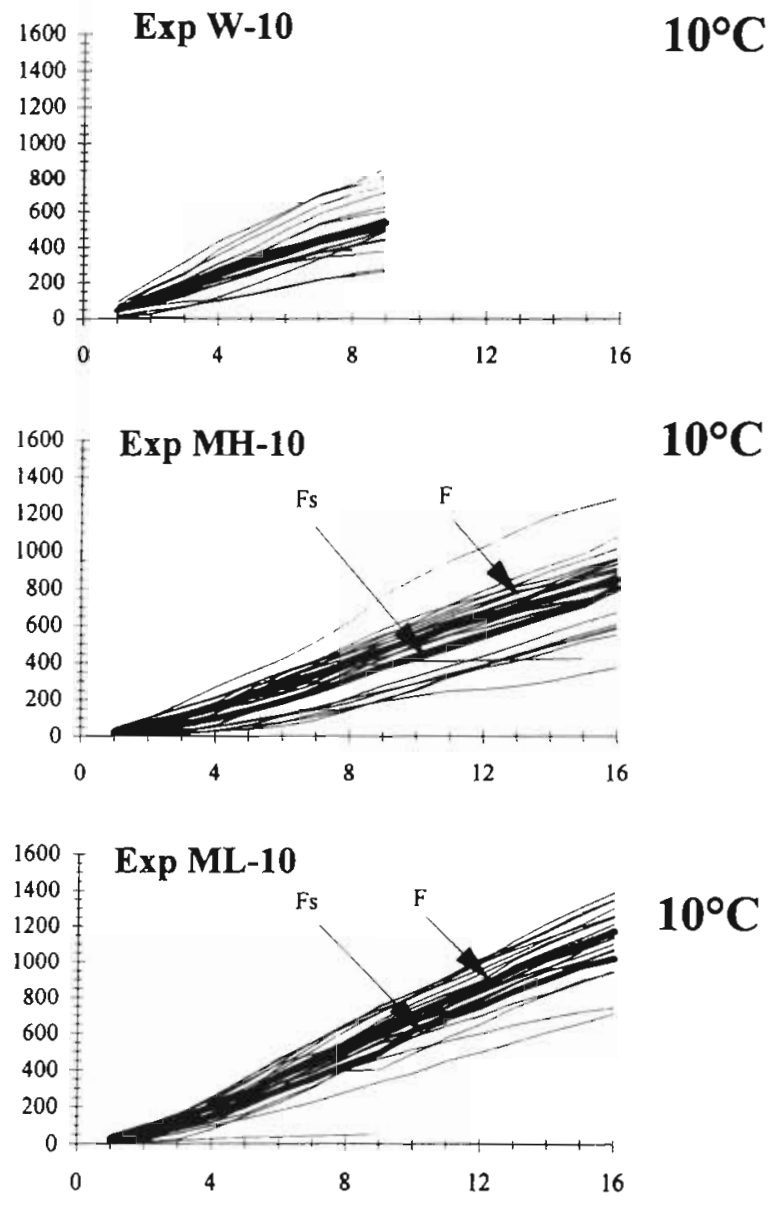

Fig. 4. Calanus finmarchicus. (A) Mean faecal pellet production with time for females incubated at 5 (Expts W-5 and MH-5) and $10^{\circ} \mathrm{C}$ (Expts W-10, MH-10 and ML-10). Dashed line and solid line represent females with and without a spermatophore at start of experiments, respectively. Vertical bars indicate standard error. Notice that the temporal scale in Expt W-5 is different than in other experiments. (B) Individual cumulative faecal pellet production. Thick lines represent mean cumulative rates of females 
Table 4. Calanus finmarchicus. Mean prosome length, width, egg diameter and oil sac volume for the 5 experiments (i.e. the tirst 5 lines as in Table 3) and for females (F) and C5 caught before respective experiences (no $C 5$ were found in March). Mean values that share the same superscripted letter are not significantly different at $5 \%$ (multiple comparisons were done successively for females from experiments, and females and C5 caught before experiments). $\mathrm{n}$ : number of females, SD: standard deviation

\begin{tabular}{|c|c|c|c|c|c|c|c|c|c|c|c|}
\hline & & $\mathrm{n}$ & $\begin{array}{c}\text { Prosome } \\
\text { length }(\mu \mathrm{m})\end{array}$ & $S D$ & $\begin{array}{l}\text { Prosome } \\
\text { width }(\mu \mathrm{m})\end{array}$ & $\mathrm{SD}$ & $\mathrm{n}$ & $\begin{array}{l}\text { Egg dia- } \\
\text { meter }(\mu \mathrm{m})\end{array}$ & $\mathrm{SD}$ & $\begin{array}{l}\text { Oil sac volume } \\
\qquad\left(10^{4} \mu^{3}\right)\end{array}$ & $\mathrm{SD}$ \\
\hline $5^{\circ} \mathrm{C}$ & Expt W-5 & 31 & $2610^{a}$ & 160 & 750 & 60 & 50 & $147^{a}$ & 10 & $82^{\circ}$ & 447 \\
\hline $5^{\circ} \mathrm{C}$ & Expt $M H-5$ & 19 & $2970^{c}$ & 110 & 900 & 60 & 50 & $147^{a}$ & 4 & $9658^{d}$ & 4856 \\
\hline $10^{\circ} \mathrm{C}$ & Expt W-10 & 23 & $2830^{c}$ & 150 & 830 & 70 & 50 & $148^{\mathrm{a}}$ & 9 & $1939^{b}$ & 2570 \\
\hline $10^{\circ} \mathrm{C}$ & Expt $\mathrm{MH}-10$ & 24 & $2930^{c}$ & 80 & 870 & 40 & 50 & $147^{\mathrm{a}}$ & 8 & $7270^{c d}$ & 4639 \\
\hline $10^{\circ} \mathrm{C}$ & Expt ML-10 & 25 & $2760^{\mathrm{b}}$ & 90 & 780 & 70 & 50 & $147^{\mathrm{a}}$ & 8 & $2938^{b c}$ & 2750 \\
\hline Before & F March & 30 & $2570^{\mathrm{a}}$ & 150 & 740 & 50 & & & & $272^{\circ}$ & 1041 \\
\hline \multirow[t]{6}{*}{ Expts } & F May & 30 & $2780^{\mathrm{b}}$ & 100 & 800 & 60 & & & & $6696^{b}$ & 3047 \\
\hline & $\mathrm{FMH}$ & 35 & $2910^{c}$ & 90 & 840 & 60 & & & & $15899^{\circ}$ & 5403 \\
\hline & F ML & 37 & $2780^{\mathrm{b}}$ & 90 & 780 & 50 & & & & $8946^{b}$ & 2669 \\
\hline & C5 May & 30 & $2550^{\mathrm{b}}$ & 70 & 790 & 50 & & & & $20131^{d}$ & 5229 \\
\hline & $\mathrm{C5} \mathrm{MH}$ & 30 & $2560^{\mathrm{b}}$ & 100 & 810 & 50 & & & & $24858^{b}$ & 7128 \\
\hline & $\mathrm{C} 5 \mathrm{ML}$ & 30 & $2430^{\circ}$ & 90 & 740 & 50 & & & & $17542^{\circ}$ & 5290 \\
\hline
\end{tabular}

Table 4). Mean prosome length increased with mean prosome width. Significant differences were found between the 5 mean prosome lengths $(F=35.5, \mathrm{p}<$ 0.001). Multiple comparisons distinguished 3 size groups. The prosome length of females from Mesocosm L (Expt ML-10) was significantly less than that from Mesocosm $\mathrm{H}$ (Expts $\mathrm{MH}-5$ and $\mathrm{MH}-10$ ). There was no significant difference in egg diameter among experiments $(F=0.377, \mathrm{p}=0.825)$. Equivalent patterns were found for copepodite stage C5 and females preserved before experiments, e.g. those from the Mesocosm $\mathrm{H}$ were significantly the largest (Table 4).

\section{Individual lipid content}

The relative oil sac volume was estimated for copepodite stage $\mathrm{C} 5$ and females preserved before and after experiments (Fig. 5A,B, respectively). Relative values permit the comparison of females which have grown at different periods of the year (e.g. wild females caught in March with the other ones caught in May). However, all statistics have been undertaken directly on lipid volumes (Table 4), since this permits one to show, for example, a significant difference between lipid contents of $\mathrm{C} 5$ from the 3 origins ( $\mathrm{Hc}=17.4, \mathrm{p}<$ 0.001 ), which otherwise would have been masked with relative values. For Expt W-5 (started in March), the lipid content was already very low in females before the experiment. The Kruskal-Wallis test showed a significant difference between the initial lipid content of females from the different origins ( $\mathrm{Hc}=105, \mathrm{p}<0.001$ ). Females from Mesocosm H (Expts MH-5 and MH-10) had the highest value (see Table 4 for results of the multiple comparisons). The lipid content of copepodite C5 (Fig. 5A) was much higher than in females prior to experimentation (Fig. 5B). Lipid catabolism was evident during the experiments since lower lipid contents were found afterward (Fig. 5B). Females from Meso$\operatorname{cosm} \mathrm{H}$ showed the least reduction in lipids $(39 \%$ at $5^{\circ} \mathrm{C}$ in Expt $\mathrm{MH}-5$ and $54 \%$ at $10^{\circ} \mathrm{C}$ in Expt $\mathrm{MH}-10$ ). The strongest decreases in lipids were seen in females from Expt W-10 (71\%) and Expt ML-10 (67\%). The reproductive index (RI) (Fig. 5C) indicates the proportion of mature females prior to experimentation (Plourde \& Runge 1993). The highest RI values appeared to be related to the lowest lipid volumes before the experiments (Fig. 5B). Indeed, females collected before Expt $W-5$ had very low lipid content and most of them had well-developed gonads ( $\mathrm{RI} \approx 0.9$ ). In contrast, young moulted females from Mesocosm $\mathrm{H}$ before Expts $\mathrm{MH}-5$ and $\mathrm{MH}-10$ had low RI and high lipid content.

\section{Factors influencing individual egg production}

Variability of individual mean egg production within each population is shown in Fig. 6 as a function of 2 independent variables: (1) prosome length and (2) individual mean faecal pellet production. A multilinear regression model was used to determine the influence of both these variables on egg production (see 'Methods'). The significance of both regression parameters is presented in Table 5. For wild females (Expts W-5 and W-10), neither prosome length nor individual mean faecal pellet production were significantly related to individual mean egg production. In contrast, the egg production of each female from Mesocosm $\mathrm{H}$ (Expts $\mathrm{MH}-5$ and $\mathrm{MH}-10$ ) was significantly related to the faecal pellet production and the egg production of each female from Mesocosm L (Expt ML-10) was positively correlated to the prosome length. 


\section{DISCUSSION}

\section{Effect of temperature}

Temperature is known to influence fecundity by affecting the spawning interval rather than the clutch size (Hirche 1990, Kiørboe \& Sabatini 1995, Hirche et al. 1997). This study allowed us to compare egg production rates of females incubated at 5 and $10^{\circ} \mathrm{C}$ (Table 3 , Analysis 2j. Based on all experiments, we found a $Q_{10}$ of 2.2 , but if we only considered Expts $\mathrm{MH}-5$ and $\mathrm{MH}-10$ (same young females from Mesocosm $\mathrm{H}$ ), a $Q_{10}$ of 3.7 was found. Carlotti \& Hirche (1997) estimated in their model of egg production of Calanus finmarchicus, a $Q_{10}$ of 3.1 and Runge (1985) found a $Q_{10}$ close to 3 based on laboratory data. In this latter study, the maximum egg production at $10^{\circ} \mathrm{C}$ was lower $\left(\sim 46\right.$ eggs female $\left.{ }^{-1} \mathrm{~d}^{-1}\right)$ than those obtained in this paper in Expts $\mathrm{MH}-10$ and ML-10. However, it is similar to the rate of Expt W-10 and, in this case, the lower value is explained because nearly one-third of the females show 'abnormal' spawning activity, i.e. they stopped or never spawned, or died during the experiment. In contrast, Hirche et al. (1997) found a much higher $Q_{10}$ of 5 . Such differences might also be due to the age of females, which will be further substantiated below.

\section{Effect of female reproductive maturity and age}

Zero or low egg production rates obtained from in situ or laboratory studies are attributed either to the immature stage of the females copepods (Runge 1985, Plourde \& Runge 1993) or to their senescence (Diel \& Tande 1992, Plourde \& Runge 1993).

In the present study, the use of newly moulted females from the mesocosms permitted assessment of the effect of the reproductive maturity of the females on egg production in superabundant food conditions at 5 and $10^{\circ} \mathrm{C}$. These females were not older than $1 \mathrm{wk}$

Table 5. Summary of multiregression models for all experiments: $Y=b_{1} \times X_{1}+b_{2} \times X_{2}+$ constant, with $Y$ : individual mean egg production, $X_{1}$ : prosome length, $X_{2}$ : individual mean faecal pellet production, $b_{1}$ and $b_{2}$ : parameters of the regression for both variables. ns: not significant. Significance levels: $" p<0.05 ; " * p<0.01$

\begin{tabular}{|clcc|}
\hline & & $b_{1}$ & $b_{2}$ \\
\hline $5^{\circ} \mathrm{C}$ & Expt W-5 & ns & ns \\
& Expt MH-5 & ns & $0.578 \cdot$ \\
& Expt W-10 & ns & ns \\
$10^{\circ} \mathrm{C}$ & Expt MH-10 & ns & $0.638^{\cdot}$ \\
& Expt ML-10 & $0.111 \cdots$ & ns \\
\hline
\end{tabular}
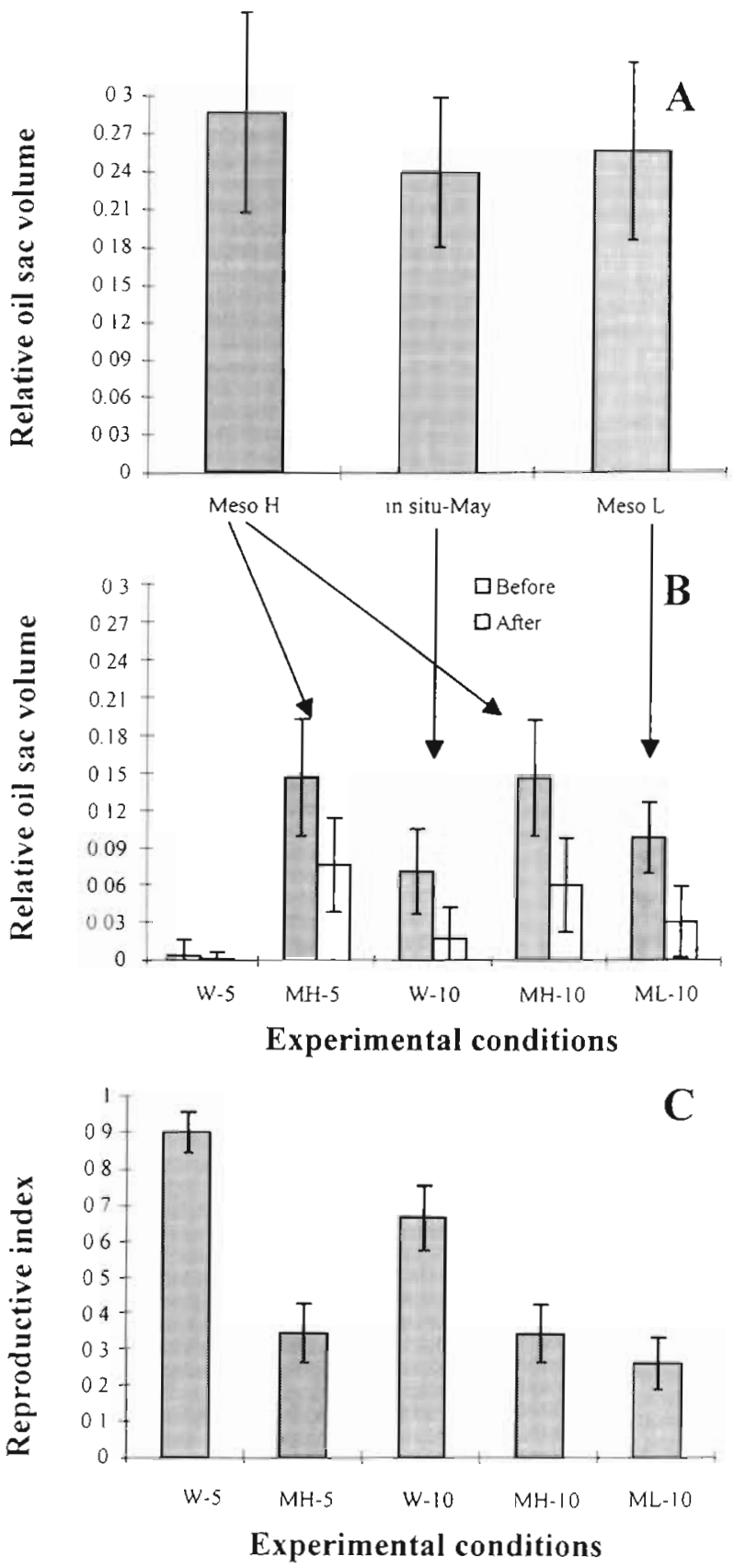

Fig. 5. Calanus finmarchicus. Relative oil sac volume measured on (A) copepodite stage C5 from mesocosms and in situ in May and (B) females caught before (grey bar) and after (white bar) experiments. (C) Reproductive index of females, i.e. proportion of mature females (Plourde \& Runge 1993) prior to experimentation. The number of females per sample varied from 21 to 37 . Vertical bars in (A) and (B) indicate standard deviation, and in (C) standard deviation calculated for frequencies

and females found initially with a spermatophore were considered even younger than those which had already lost it. The daily egg production of those young females initially increased over Expts $\mathrm{MH}-5, \mathrm{MH}-10$ and ML-10 (Fig. 3A) until optimal rates were reached. 


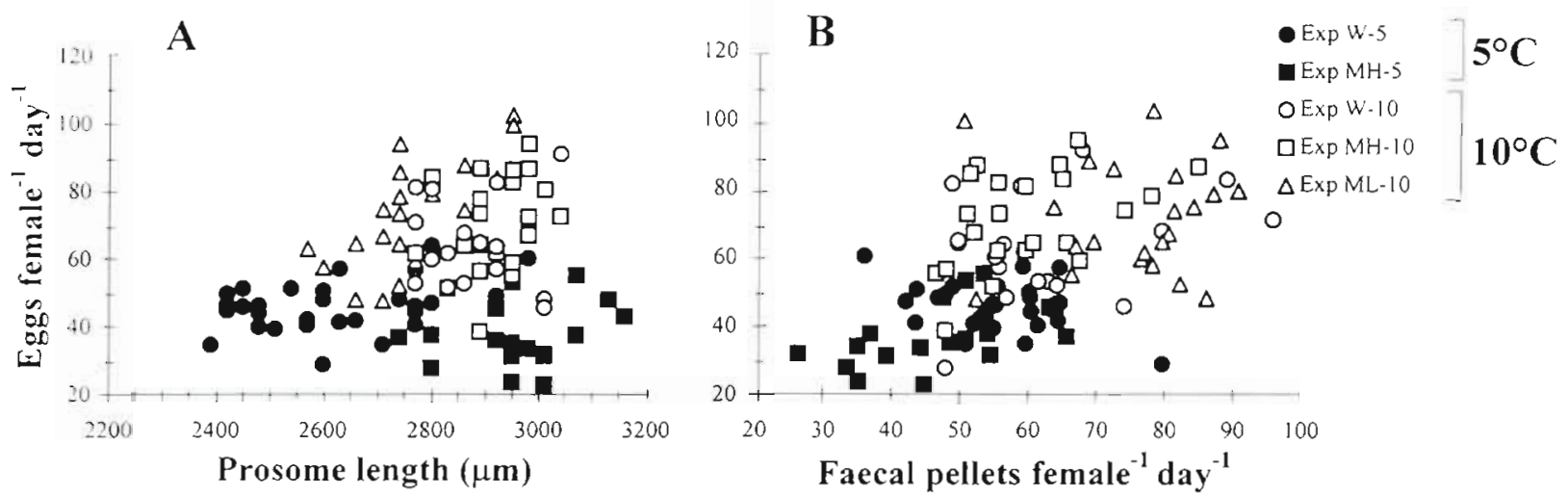

Fig. 6. Calanus finmarchicus. Individual mean egg production versus (A) prosome length and (B) individual mean faecal pellet production. Females held at $5^{\circ} \mathrm{C}$ originated from in situ populations caught in March ( ) and mesocosm. H ( $\square$ ); females held at $10^{\circ} \mathrm{C}$ originated from in situ populations caught in May (O), mesocosm $\mathrm{L}(\Delta)$ and mesocosm $\mathrm{H}(\square)$

If the successive events from moulting to optimal spawning activity are summarised on a temporal scale (Fig. 7), the following periods can be estimated: (1) from moulting to fertilisation inside mesocosms $\left(\Delta T_{0}\right)$ and from fertilisation to (2) the loss of the spermatophore $\left(\Delta T_{1}\right)$, (3) the first clutch $\left(\Delta T_{2}\right)$, and (4) the optimal spawning activity $\left(\Delta T_{3}\right) . \Delta T_{2}$ and $\Delta T_{3}$ (but not $\Delta T_{1}$ ) were assumed dependent of temperature

The very high success of fertilisation of the young females inside the mesocosms, as in the natural environment (Marshall \& Orr 1955), suggests a $\Delta T_{0}$ of around $1 \mathrm{~d}$, which is relevant to observations made by Tsuda \& Miller (1998) on the mating of Calanus marshallae held in a large 2501 container. $\Delta T_{1}$ was estimated to be $2 \mathrm{~d}$

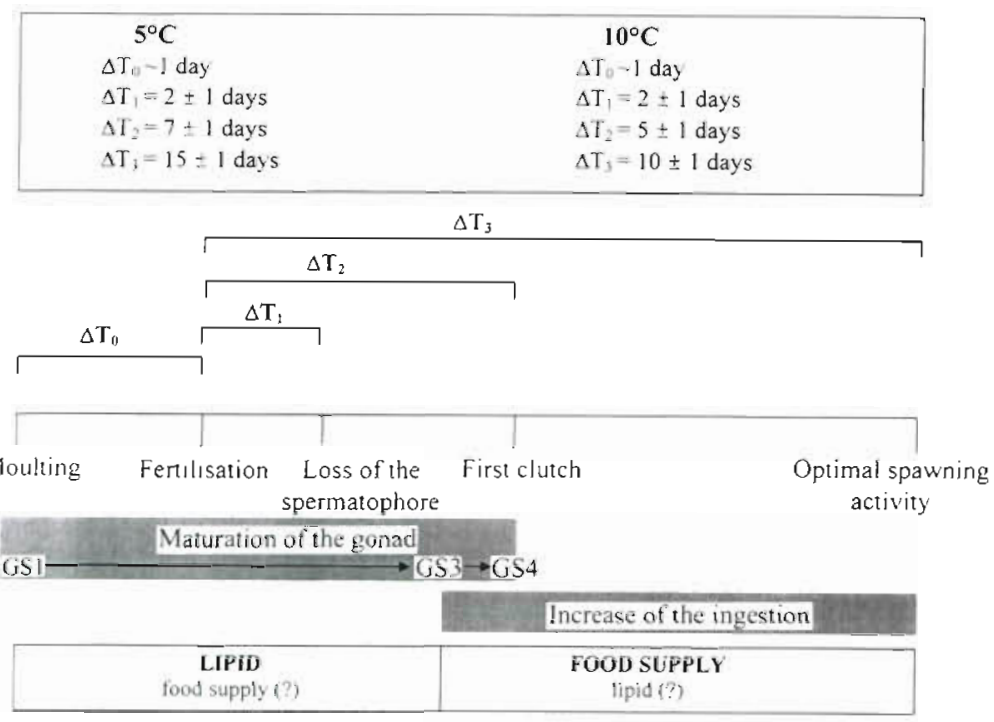

Fig. 7 Calanus finmarchicus. Conceptual model of different events between moulting and optimal spawning activity in newly moulted females in superabundant food conditions. GS1 to GS4 correspond to gonad developmental stages described by Niehoff \& Hirche (1996) in the present study. At $5^{\circ} \mathrm{C}$ (Expt $\left.M H-5\right), \Delta T_{2}$ and $\Delta T_{3}$ were estimated to be 7 and $15 \mathrm{~d}$, respectively, whereas at $10^{\circ} \mathrm{C}$ (Expts MH-10 and ML-10), $\Delta T_{2}$ and $\Delta T_{3}$ were 5 and $10 \mathrm{~d}$. These results emphasise the importance of the reproductive development of females in order to understand the variability of egg production and to explain why the mean rates at $5^{\circ} \mathrm{C}$ (Table 3 ) were significantly lower in Expt MH-5 (37.6 eggs female ${ }^{-1} \mathrm{~d}^{-1}$ ) than in Expt W-5 (46.5 eggs female ${ }^{-1} \mathrm{~d}^{-1}$ ).

Marshall \& Orr (1955) determined that well-fed females caught in situ with spermatophores would start laying eggs in the laboratory within approximately 1 wk. In Plourde \& Runge (1993), the in situ egg production rate increased markedly around 5 to $10 \mathrm{~d}$ after the chlorophyll peak was observed in the Lower St. Lawrence Estuary. In the same study, $90 \%$ of initially immature females held at the laboratory in enriched sea water became mature after $\sim 8$ and $\sim 11$ d at 5.5 and $1.0^{\circ} \mathrm{C}$ respectively. All these results fit well with our conceptual reproductive model (Fig, 7).

From a physiological point of view, the delay in the spawning activity of young females can be due to the time required for the gonad maturation (Fig. 7), which has already started at the copepodite stage C5 (Tande \& Hopkins 1981, Grigg \& Bardwell 1982). The full maturation processes of the gonad described recently by Niehoff \& Hirche (1996) might last at least until the first clutch was produced and require most of the lipid stored previously (see Fig 5; Gatten \& Sargent 1980, Runge 1984, Hopkins et al. 1985, Sargent \& FalkPetersen 1988, Hirche 1996a,b). How- 
ever, the completion of gonad maturation should require food supply (Fig. 7; Tande 1982, Diel \& Tande 1992, Ohman \& Runge 1994, Hirche 1996b). Compared to histological data from Niehoff \& Hirche (1996), the final stage of gonad maturation which requires food might concur with the transition time between the last 2 gonad developmental stages (from GS3 to GS4, Fig. 7), i.e. during vitellogenesis 2. Finally, the period from the production of the first clutch to the optimal rate and to its maintenance seems dependent on food supply (Fig. 7; Marshall \& Orr 1955, 1961, Checkey et al. 1992, Diel \& Tande 1992), and not lipid stores.

Senescence has also been reported to explain low values of egg production in copepods (Hirche 1996b). In our experiments, the spawning activity never decreased and females in Expt W-5 laid up to 2657 eggs, with $50 \%$ of the females laying $>2000$ eggs over a period of $44 \mathrm{~d}$. These high values were similar to those obtained by Hirche (1990) at $0^{\circ} \mathrm{C}$ (up to 3101 over 77 d). The present study shows that Calanus finmarchicus can produce a substantial number of eggs over a sustained period, which generally overlaps with the spring phytoplankton bloom. On the other hand, the estimate of the total in situ fecundity is often much lower ( 600 eggs, Diel \& Tande 1992), and the environmental factors governing the life span of $C$. finmarchicus are still not fully understood.

\section{Influence of seasonal origin of the females on their reproductive processes}

Calanus finmarchicus copepodites (mainly C5) are known for their migration into deep waters and their decrease in metabolic cost during winter time (Hallberg \& Hirche 1982, Tande 1982, Tande \& Slagstad 1982, Hirche 1996b). Around February, they migrate into surface waters to reproduce and develop into 1 (at least) cohort generation. Obviously, the reproductive strategy of females from the overwintering stock might differ from new generation females

In the present study, the fecundity of wild females (unknown age) from the Raunefjord collected in March and May (Expts $W-5$ and $W-10$, respectively) was compared to that of young females from mesocosms. The females of Expt W-5 were certainly from the overwintering population and had moulted into adults at least 1 mo earlier. They were collected well before the spring bloom (pers. obs.). Their lipid content was very low and their gonad was almost fully matured at their collection (Fig. 5B,C). Almost all their lipid should have been used for gonad maturation, for metabolism and possibly to supply first clutches (Diel \& Tande 1992). The egg production of these females increased during the first days of Expt W-5, which suggests that they had just started their reproductive phase in the fjord.

In contrast, the females of Expt $\mathrm{W}-10$ were probably from the first new generation. They may have come from eggs developed during the spring bloom and moulted into adults around the beginning of May. Thus, these females might be relatively young, still having some lipids when they were collected (Fig. 5B,C). They produced optimal spawning rates from the very beginning of Expt W-10 and it is likely that these females had already started their life span in the fjord, characterised at that time of the year by relatively high chlorophyll

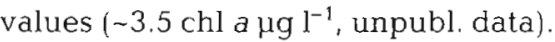

\section{Effect of the feeding history}

One objective of the present study was to estimate the influence of feeding history on fecundity and egestion rates. This can be explored by comparing results from Expts MH-10 and ML-10. Females of both experiments were from the same batch of eggs and therefore of similar age and genetic background. The only difference was the feeding history; females from Expts $\mathrm{MH}-10$ and ML- 10 were acclimated to high (Mesocosm $\mathrm{H}$ ) and low food levels (Mesocosm L), respectively.

The prosome length (Table 4) and the carbon content of the females prior to experimentation were significantly higher for females from Mesocosm $\mathrm{H}$ (Expt $\mathrm{MH}-10,222 \mu \mathrm{g} \mathrm{C}$ female $^{-1}$, Hygum et al. unpubl. b) than that from Mesocosm L (Expt ML-10, $110 \mu \mathrm{g} \mathrm{C}$ female ${ }^{-1}$, Hygum et al. unpubl. b). However, no significant difference was found in fecundity between the 2 experiments (Table 4); this was also true for egg diameter (Table 3). This latter result was not surprising considering the results of Guisande \& Harris (1995), who found that egg diameter was related to food concentration during the spawning experiments. In contrast, the mean egestion rate of Expt ML-10 was significantly higher than that found in Expt $\mathrm{MH}-10$ (Table 3).

To interpret these results, the following question has to be raised: can results for egestion obtained in Expts $\mathrm{MH}-10$ and $\mathrm{ML}-10$ be compared and converted into terms of ingestion? Two patterns suggest that this is effectively possible. Firstly, egestion rate has been found to be linearly related to the ingestion in a previous study run in conditions close to ours (Nejstgaard 1997. see also Gamble 1978). Secondly, volumes of faecal pellets collected once in both experiences were found to be significantly not different. It is possible that faecal pellet volume varied during experiments or that faecal pellet density was different in both experiments However, we assume this is not the case and that females from Expt ML-10 had the higher maximum ingestion rate (due to superabundant food, i.e. a hunger 
response), and the lower gross efficiency (i.e. the ratio of fecundity to ingestion) compared to those from Expt $\mathrm{MH}-10$. Alternatively, the hunger response of females from Expt ML-10 could be explained to compensate either for lower assimilation rates or for any deficiencies in some body constituents (e.g. nitrogen and protein as suggested in Checkley 1980 or Hirche 1996b) finally, for producing the same number of eggs as females in Expt $\mathrm{MH}-10$. Such interpretations are in accordance with Landry \& Hassett (1985) and Hassett \& Landry $(1983,1990)$. In both of the latter studies, the authors found higher values of ingestion for Calanus pacificus females previously acclimated to long-term food-limiting conditions. A similar hunger response was found by Frost (1972) and Runge (1980) for C. pacificus females previously starved for $1 \mathrm{~d}$. The females in Expt W-5 also showed that initially high faecal pellet production rates from Day 7 to Day 32 were followed by a significant decrease (Fig. 4A), which may be due to the fact that they were collected in the fjord prior to the onset of the bloom.

Results of Expt ML-10 indicated that the effect of feeding history on feeding processes (hence gross efficiency) can last up to $15 \mathrm{~d}$. Therefore, the use of fecundity as a feeding index for Calanus sp. may be reconsidered (Kiørboe et al. 1985, Hirche 1996b).

The multiregression model used to explain variability in individual mean egg production rates (Table 5) showed that the individual fecundity in Expt ML-10 was related to prosome length. As previously shown, females in Expt ML-10 had the highest egestion rate (Table 3). Clearly, all females had reached maximum metabolic capacity, which may depend on their individual characteristics such as their prosome length explaining why the largest females in Expt ML-10 were the most productive. In contrast, individual fecundity of females from Mesocosm $\mathrm{H}$ in Expts $\mathrm{MH}-5$ $\left(5^{\circ} \mathrm{C}\right)$ and $\mathrm{MH}-10\left(10^{\circ} \mathrm{C}\right)$ was related to mean faecal pellet production (Table 5). These females had not reached their maximum metabolic capacity, as it was not necessary for optimal production. In this case, it was the hungriest females which had the highest egg production rates. Factors influencing individual fecundity are thus a function of present as well as previous environmental conditions (i.e. copepodite growth rate), which can partly explain the relationship between clutch size and prosome length found by some authors (Runge 1984, Runge \& Plourde 1996) but not others (Hirche 1990).

\section{CONCLUSION}

The use of female copepods previously reared in mesocosms permits investigation of the effect of 2 fac- tors (age and feeding history) on fecundity and egestion. Low fecundity was found in young females over a significant time period. A conceptual model was proposed to summarise the different steps from moulting to optimal spawning activity. These results enable the influence of the seasonal origin of wild females on fecundity processes to be assessed. Although feeding history did not influence fecundity, higher faecal pellet production was observed in females coming from a low food environment, suggesting that different gross efficiencies are a function of the feeding history. This study emphasises that both age and feeding history may be as important as other environmental factors such as temperature or food supply in explaining the variability in fecundity and egestion. In this study, the effect of age and feeding history was monitored for females held in excess food, but it might be even more pronounced when food concentrations are lower, such as is usually the case in the natural environment.

Acknowledgements. This study was financially supported by the Commission of the European Community through contract MAS3-CT95-0039 (TASC) and by the TMR (Training and Mobility of Researchers) programme from the European Union through contract no. ERBFMGECT950013. We especially thank Dr S. Dallot and Dr C. Rouvière, Station Zoologique, Villefranche-sur-Mer, for support with statistics and introduction to METAMORPH 2.75 software respectively, Dr $P$. Thor, Roskilde University, for support with the algae culture, B. Vaaja, The Norwegian College of Fishery Science, University of Tromse, for assistance with the egg counting, DT P. Virtue, Station Zoologique, Villefranche-sur-Mer, for linguistic corrections, Dr R. Harris and Dr X. Irigoien, Plymouth Marine Laboratory, for helpful comments on the manuscript, and the 3 referees for their critical review of the manuscript.

\section{LITERATURE CITED}

Båmstedt U (1988) Ecological significance of individual variability in copepod bioenergetics. Hydrobiologia 167/168: $43-59$

Båmstedt U, Tande K (1988) Physiological responses of Calanus finmarchicus and Metridia longa (Copepoda: Calanoida) during the winter-spring transition. Mar Biol 99:31-38

Cabal J, Harris LR, Head EJH (1997) Egg production rates of Calanus finmarchicus in the Northwest Atlantic (Labrador Sea). Can J Fish Aquat Sci 54:1270-1279

Carlotti F, Hirche HJ (1997) Growth and egg production of female Calanus finmarchicus: an individual-based physiological model and experimental validation. Mar Ecol Prog Ser 149:91-104

Carlotti F, Rey C, Javanshir A, Nival S (1997) Laboratory studies on egg an faecal pellet production of Centropages typicus: effect of age, effect of temperature, individual variability. J Plankton Res 19(8):11.43-1165

Checkley DM (1980) The egg production of marine planktonic copepod in relation to food supply: laboratory studies. Limnol Oceanogr 25(3):430-446

Checkley DM, Dagg MJ, Uye SI (1992) Feeding, excretion and egg production by individuals and populations of the 
marine, planktonic copepods, Acartia spp. and Centropages furcatus. J Plankton Res 14(1):71-96

Dagg $M$ (1977) Some effects of patchy food environments on copepods. Limnol Oceanogr 22:99-107

Diel S, Tande KS (1992) Does the spawning of Calanus finmarchicus in high latitudes follow a reproductive pattern? Mar Biol 113:21-31

Egge JK. Heimdal BR (1994) Blooms of phytoplankton including Emiliana huxleyi (Haptophyta). Effects of nutrient supply in different N:P ratios. Sarsia 79:333-348

Frost BW (1973) Effects of size and concentration of food particles on the feeding behaviour of the marine planktonic copepod Calanus pacificus. Limnol Oceanogr 17(6):805-815

Gamble JC (1978) Copepod grazing during a declining spring phytoplankton bloom in the northern North Sea. Mar Biol 49:303-315

Gatten RR, Sargent JR (1980) On the nutrition and metabolism of zooplankton. XIV. Utilization of lipid by Calanus helgolandicus during maturation and reproduction. J Mar Biol Assoc UK 60:391-399

Grigg H, Bardwell SJ (1982) Seasonal observations on moulting and maturation in stage $\mathrm{V}$ copepodites of Calanus finmarchicus from the Firth of Clyde. J Mar Biol Assoc UK 62: $315-327$

Guisande C, Harris R (1995) Effect of total organic content of eggs on hatching success and naupliar survival in the copepod Calanus helgolandicus. Limnol Oceanogr 40(3):476-482

Hallberg $E$, Hirche HJ (1982) Differentiation of mid-gut in aduits and overwintering copepodids of Calanus finmarchicus and C. helgolandicus. J Exp Mar Biol Ecol 48: 283-295

Harris RP, Samain JF, Moal J, Martin-Jézéquel V, Poulet SA (1986) Effects of algal diet on digestive enzyme activity in Calanus helgolandicus. Mar Biol 90:353-361

Hassett RP, Landry MR (1983) Effects of food-level acclima. tion on digestive enzyme activities and feeding behavior of Calanus pacificus. Mar Biol 75:47-55

Hassett RP, Landry MR (1988) Short-term changes in feeding and digestion by the copepod Calanus pacificus. Mar Biol 99:63-74

Hassett RP, Landry MR (1990) Effects of diet and starvation on digestive enzyme activity and feeding behavior of the marine copepod Calanus pacificus. J Plankton Res 12(5): $991-1010$

Hay S (1995) Egg production and secondary production of common North Sea copepods: field estimates with regional and seasonal comparisons. ICES J Mar Sci 52: $315-327$

Hirche HJ (1990) Egg production of Calanus finmarchicus at low temperature. Mar Biol 106:53-58

Hirche HJ (1996a) Diapause in the marine copepod, Calanus finmarchicus-a review. Ophelia 44:129-143

Hirche HJ (1996b) The reproductive biology of the marine copepod, Calanus finmarchicus-a review. Ophelia 44 $111-128$

Hirche HJ, Meyer U, Niehoff B (1997) Egg production of Calanus finmarchicus-effect of temperature, food and season. Mar Biol 127:609-620

Hopkins CCE, Tande KS, Grønvik S, Sargent JR, Schweder T (1985) Ecological investigations of the zooplankton community of Balsfjorden, northern Norway: growth, and quantification of condition, in relation to overwintering and food supply in Metridia longa, Calanus finmarchicus, Thysanoessa inermis and Thysanoessa raschi. In: Gray JS Christiansen ME (eds) Biology of polar regions and effects of stress on marine organisms. John Wiley \& Sons Ltd, Chicester, $p$ 83-101
Huntley M (1988) Feeding biology of Calanus: a new per spective. Hydrobiologia 167/168:83-99

Hygum BH, Rey C, Hansen BW (in press a) Growth and development rates of Calanus finmarchicus (Gunnerus) nauplii during a diatom spring bloom - a mesocosm study. Mar Biol

Hygum BH, Rey C, Hansen BW, Tande K (in press b) Rearing Calanus finmarchicus in mesocosms: copepodite growth and development rates vs. food quantity. Mar Biol

Kiørboe T, Sabatini M (1995) Scaling of fecundity, growth and development in marine planktonic copepods. Mar Ecol Prog Ser 120:285-298

Kiørboe T, Mohlenberg F, Risgard HU (1985) In situ feeding rates of planktonic copepods: a comparison of four methods. J Exp Mar Biol Ecol 88:67-81

Laabir M, Poulet SA, Ianora A (1995) Measuring production and viability of eggs in Calanus helgolandicus. J Plankton Res 17(5): 1125-1142

Landry MR, Hassett RP (1985) Time scales in behavioral, biochemical, and energetic adaptations to food-limiting conditions by a marine copepod. Arch Hydrobiol Beih Ergeb Limnol 21:209-221

Marshall SM, Orr AP (1955) The biology of marine copepod Calanus finmarchicus (Gunnerus). Oliver \& Boyd, London

Marshall SM, Orr AP (1961) On the biology of Calanus finmarchicus. XII. The phosphorus cycle: excretion, egg production, autolysis. J Mar Biol Assoc UK 41:463-488

McLaren IA, Leonard A (1995) Assessing the equivalence of growth and egg production of copepods. ICES J Mar Sci $52: 397-408$

Miralto A, Ianora A, Poulet SA, Romano G, Laabir M (1996) Is fecundity modified by crowding in the copepod Centropages typicus? J Plankton Res 18(6): 1033-1.040

Nejstgaard JC (1997) Food web dynamics in flagellate-dominated marine environments. Trophic interaction between haptophytes, calanoid copepods and microzooplankton. University of Bergen

Niehoff B, Hirche HJ (1996) Oogenesis and gonad maturaton in the copepod Calanus finmarchicus and the prediction of egg production from preserved samples. Polar Biol 16 : $601-602$

Nival S, Pagano M. Nival P (1990) Laboratory study of the spawning rate of the calanoid copepod Centropages typicus effect of fluctuating food supply. J Plankton Res 12:535-547

Ohman MD, Runge JA (1994) Sustained fecundity when phytoplankton resources are in short supply: omnivory by Calanus finmarchicus in the Gulf of St Lawrence. Limnol Oceanogr 39(1):21-36

Paffenhöfer GA (1994) Variability due to feeding activity of individual copepods. J Plankton Res 16(6):617-626

Peterson WT (1988) Rates of ega production by the copepod Calanus marshallae in the laboratory and in the sea off Oregon, USA. Mar Ecol Prog Ser 47:229-237

Peterson WT, Tiselius P, Kiørboe T (1991) Copepod egg production, moulting and growth rates, and secondary production, in the Skagerrak in August 1988. J Plankton Res 13(1):131-154

Plourde S, Runge JA (1993) Reproduction of the planktonic copepod Calanus finmarchicus in the Lower St Lawrence Estuary: relation to the cycle of phytoplankton production and evidence for a Calanus pump. Mar Ecol Prog Ser 102: $217-227$

Pond D, Harris R, Head R, Harbour D (1996) Environmental and nutritional factors determining seasonal variability in the fecundity and egg viability of Calanus helgolandicus in coastal waters off Plymouth, UK. Mar Ecol Prog Ser 143: $46-63$ 
Poulet SA, lanory A, Laabir M, Klein Breteler WCM (1995) Towards the measurement of secondary production and recruitment in copepods. ICES J Mar Sci 52:359-368

Runge JA (1980) Effect of hunger and season on the feeding behavior of Calanus pacificus. Limnol Oceanogr 25(1): $134-145$

Runge JA (1984) Egg production of the marine, planktonic copepod, Calanus pacificus Brodsky: laboratory observations. J Exp Mar Biol Ecol 74:53-66

Runge JA. (1985) Egg production rates of Calanus finmarchicus in the sea off Nova Scotia. Ergeb Limnol 21:33-40

Runge JA (1987) Measurement of egg production rate of Calanus finmarchicus from preserved samples. Can J Fish Aquat Sci 44:2009-2012

Runge JA, Plourde S (1996) Fecundity characteristics of Calanus finmarchicus in coastal waters of Eastern Canada. Ophelia 44:171-187

Saiz E, Calbet A, Trepat I, Irigoien X, Alcaraz M (1997) Food availability as a potential source of bias in the egg production method for copepods. J Plankton Res 19(1):1-14

Sargent JR, Falk-Petersen S (1988) The lipid biochemistry of calanoid copepods. Hydrobiologia 167/168:101-114

Scherrer B (1984) Biostatistique. Gaëtan Morin, Québec

Sekiguchi H, McLaren IA, Corkett CJ (1980) Relationship

Editorial responsibility: Otto Kinne (Editor)

Oldendorf/Luhe, Germany between growth rate and egg production in the copepod Acartia clausi hudsonica. Mar Biol 58:133-138

Smith SL, Lane PV (1.985) Laboratory studies of the marine copepod Centropages typicus: egg production and development rates. Mar Biol 85:153-162

SYSTAT 70 (1997) New statistics. SPSS Inc, Chicago, IL

Tande KS (1982) Ecological investigations on the zooplankton community of Balsfjorden, Northern Norway: generation cycles, and variations in body weight and body content of carbon and nitrogen related to overwintering and reproduction in the copepod Calanus finmarchicus (Gunnerus). J Exp Mar Biol Ecol 62:129-142

Tande KS, Hopkins CCE (1981) Ecological investigations of the zooplankton community of Balsfjorden, northern Norway: the genital system in Calanus finmarchicus and the role of gonad development in overwintering strategy. Mar Biol 63:159-164

Tande KS, Slagstad D (1982) Ecological investigations on the zooplankton community of Balsfjorden, Northern Norway: seasonal and short-time variations in enzyme activity in copepodite stage V and VI males and females of Calanus finmarchicus (Gunnerus). Sarsia 67(1):63-68

Tsuda A, Miller CB (1998) Mate-finding behavior in Calanus marshallae Frost. Philos Trans R Soc Lond 353:713-720

Submitted: June 8, 1998; Accepted: January 7, 1999

Proofs received from author(5): October 14, 1999 